\title{
Obraz świeckich patronów i seniorów Kościoła ewangelicko-reformowanego w piśmiennictwie XVI i XVII wieku
}

\section{Abstract \\ The Image of Lay Patrons and Seniors of The Polish Reformed Church in $16^{\text {th }}$ and $17^{\text {th }}$ Century Writings}

The paper presents opinions coming from the $16^{\text {th }}$ and $17^{\text {th }}$ centuries pertaining to lay patrons and seniors of the Polish Reformed Church. Dedications attached to confessional publications emphasised the significant role of, among others, Krzysztof Dorohostajski, the Radziwiłł family of Biržai, the Gorajski family, the Leszczyński family as protectors of their co-religionists, book sponsors, founders of Protestant churches, and patrons of institutionalized education. The loss of patrons was considered God's punishment. Documents reporting synodal meetings provided specific actions that should be undertaken by lay senior members of a community. A Protestant assembly in Kedainiai in 1630 presented the criteria of the selection of lay seniors and their scope of duties, which included: supervising the behaviours of their co-religionists, admonishing misbehaving gentlemen and ministers, regular participation in assemblies, etc. Documents from provincial synods of Unitas Lithuaniae featured both praises of its patrons' activities, particularly of Krzysztof Radziwiłł, and critique of financial support they offered to Protestant churches and ministers. 
Key words: Polish Reformation, patronage, Radziwiłł family, Gorajski family, Leszczyński family

W Kościele ewangelicko-reformowanym rola świeckich patronów była wyjątkowa, pełnili bowiem funkcje dyrektorów synodów, otaczali prawną opieką współwyznawców, nadzorowali ich postępowanie, ale także wspierali materialnie oraz wizytowali zbory i szkoły, a nawet wypowiadali się w sprawach doktrynalnych. Ważną rolę odgrywali też seniorzy świeccy - „wybierani na synodach członkowie kolegialnych władz zborów ewangelicko-reformowanych we wszystkich dystryktach, czyli jednostkach administracyjnych kościoła ewangelicko-reformowanego w Rzeczypospolitej"1. Brali oni udział w synodach prowincjonalnych, mogli upominać duchownych, a nawet zawieszać ich w urzędzie, wobec władz byli rzecznikami swego Kościoła $^{2}$. O znaczeniu ewangelickiego patronatu w Rzeczypospolitej świadczą zarówno akta synodów, jak i prywatne oraz publiczne wypowiedzi z XVI i XVII wieku. Status tych „głosów z epoki” jest bardzo różny, najbardziej konwencjonalne są teksty o charakterze panegirycznym (dedykacje, utwory funeralne), chociaż warto w tych laudacjach odnotować zwracanie uwagi na wzorzec dobrego patrona i opis jego działań. Inny charakter miały uwagi w korespondencji oraz dokumentacja posiedzeń synodalnych, stanowiące świadectwo konkretnych starań i poczynań mecenasów ${ }^{3}$, a także seniorów świeckich na rzecz swoich współwyznawców.

1 U. Augustyniak, Państwo świeckie czy księże? Spór o rolę duchowieństwa katolickiego w Rzeczypospolitej w czasach Zygmunta III Wazy. Wybór tekstów, Warszawa 2013, s. 257, przyp. 29.

2 Zob. W. Krasiński, Walki religijne w Polsce, czyli zarys dziejów powstania i upadku reformacji w Polsce, Toledo 1925, s. 378.

3 Termin „mecenas” oznaczał w XVII wieku przede wszystkim opiekuna oświaty i Kościoła. Zob. M. Paknys, Mecenat, w: Kultura Wielkiego Księstwa Litewskiego. 
Oficjalne wypowiedzi chwalące działalność „piastunów” zborów to przede wszystkim listy dedykacyjne do wydawnictw konfesyjnych; jako adresaci przypisań występowali między innymi Radziwiłłowie birżańscy, którzy wspierali rozwój Jednoty Litewskiej swoim autorytetem i pomocą materialną4. Najbardziej spektakularnym przejawem działalności mecenasowskiej było inicjowanie i sponsorowanie kolejnych przekładów Pisma Świętego, które powstawały pod auspicjami panów na Birżach i Dubinkach. W stemmacie Biblii brzeskiej poświęconym Mikołajowi Czarnemu podkreślano znaczenie inicjatywy wydawniczej wojewody dla wszystkich „ludzi języka słowieńskiego, / Aby się chutniej spieszyli do słowa Bożego", i prognozowano, że za te pobożne starania będą wznoszone modlitwy w intencji patrona ${ }^{5}$. Inne wydawnictwa konfesyjne również eksponowały znaczącą rolę wojewody wileńskiego w krzewieniu reformacji. Wawrzyniec z Przasnysza podkreślał wpływ księcia na przyjęcie wiary ewangelickiej przez jego żonę, „wespołek z dziatkami, służebniki z służebnicami i z poddanymi swoimi”' oraz przez „prawie wszytki zacniejsze domy w Księstwie Litewskim, w Żmodzi i w Rusi”’. Autor, który dzięki poparciu Radziwiłła został kaznodzieją królewskim w Wilnie,

Analizy i obrazy, oprac. V. Ališauskas, L. Jovaiš, M. Paknys, R. Petrauskas, E. Raila, Kraków 2006, s. 335.

4 Zob. E. Bagińska, Tolerancja czy przymus wyznaniowy? Z dziejów polityki religijnej Radziwiłłów birżańskich, w: Studia nad reformacja, red. E. Bagińska, P. Guzowski, M. Liedke, Białystok 2010, s. 21; M. Jarczykowa, Radziwiłłowie birżańscy jako protektorzy wyznania ewangelicko-reformowanego $w$ pierwszej połowie XVII wieku, w: Dialog z Europa i aksjologia ewangelików reformowanych w świetle literatury i piśmiennictwa XVI-XVII wieku, red. D. Chemperek, Warszawa 2015, s. 107-135.

5 Biblia święta, to jest Księgi Starego i Nowego Zakonu, właśnie z żydowskiego, greckiego i łacińskiego, nowo na polski język z pilnościa i wiernie wyłożone, Brześć: [Stanisław Murmelius lub Cyprian Bazylik], nakładem Mikołaja Radziwiłła, 1563, s. 2 nlb.

6 Wawrzyniec z Przasnysza, Nauka o prawdziwej i o fałszywej pokucie [...], Pińczów: Daniel z Łęczycy, 1559, s. 5 nlb.

7 Ibidem. 
zachęcał Mikołaja Czarnego do dalszych starań, aby Zygmunt August „podług powinowactwa urzędu powołania swego słowo Boże prawdziwe przyjąwszy, wolne po wszystkim królestwie swoim puścił, jego i chwały prawdziwej Bożej mocnie a stale bronił”.

Po śmierci Mikołaja Czarnego opiekę nad protestantami przejął jego brat stryjeczny, imiennik - Rudy. Przypisano mu kolejną edycję Pisma Świętego, tak zwaną Biblię nieświeską. Dedykacja dla wojewody wileńskiego podkreślała jego znaczenie jako przywódcy innowierców na Litwie, a autorzy dedykacji - Hektor i Albrecht Kawieczyńscy - wychwalali religijne zaangażowanie Radziwiłła oraz prosili go o obronę dysydentów przed prześladowaniami:

Bo Wasza K[siążęca] M[iłość], nic się na żadną rzecz nie oglądając, on to zbór prze śmierć Jego K[siążęcej] M[iłości], pana brata Waszej K[siążęcej] M[iłości] strwożony i osierociały, bez omieszkania raczyłeś do obrony swej przyjąć, a jemu w onej nieledajakiej trwodze dobrej otuchy dodać. Zaczym sprzeciwnicy jego przedsięwzięcie swoje opuścić musieli, zaś wierni za tak prędką obronę i za tak możnego obrońcę Pana Boga niepomału, a słusznie wysławiali'.

Z kolei w przypisaniu do Biblii gdańskiej skierowanym do wnuka Rudego - Krzysztofa Radziwiłła - „starsi dozorcy i bracia zborów ewangelickich" zapewniali, że pobożne starania w zakresie popularyzacji nowej edycji przyniosą księciu nie tylko nagrodę po śmierci, ale także zagwarantują obfitość dóbr i łask w doczesnym życiu. Jednocześnie podkreślali wielkie zasługi Krzysztofa Radziwiłła jako patrona wyznania ewangelicko-reformowanego ${ }^{10}$.

8 Ibidem, s. 6 nlb.

9 H.A. Kawieczyńscy, Oświeconemu Książęciu i Panu, Panu Mikołajowi Radziwiłłowi [...], w: Biblia, to jest Księgi Starego i Nowego Przymierza znowu z języka ebrajskiego, greckiego i łacińskiego na polski przełożone, [Nieśwież, Zasław lub Uzda]: Daniel z Łęczycy, nakładem Macieja, Hektora i Adama Kawieczyńskich, 1572, k. $A_{2} v$.

${ }_{10}$ Oświeconemu Książęciu a Panu Jego Książęcej Mości Panu Krzysztofowi Radziwiłłowi, w: Biblia święta, to jest Księgi Starego i Nowego Przymierza z żydowskie- 
Szymon Budny ${ }^{11} \mathrm{w}$ dedykacji do swojego przekładu Nowego Testamentu nie tylko dziękował krajczemu litewskiemu Janowi Kiszce za wsparcie, ale wskazał także na przykłady innych pobożnych panów, którzy odegrali znaczącą rolę w propagowaniu wiary:

Taki był on święty król Jan Zygmunt na Węgrzech ${ }^{12}$, a tu u nas on wiecznej pamięci godny pan Mikołaj Radziwiłł ${ }^{13}$ ołyckie i nieświeskie książę etc. Taki Symeon słuckie książęe ${ }^{14}$ którego nam Pan Bóg tylko był ukazał, ale się go napatrzyć nie dał. Także i w Polszcze Lasoccy ${ }^{15}$, Oleśniccy ${ }^{16}$, Filipowscy ${ }^{17}$ i inni zbożni ludzie byli [...], także i temi czasy Bóg nie bez przyczyny tak zacne piastuny zboru swego pobra1 ${ }^{18}$.

Wymienieni przez tłumacza „zbożni ludzie” to zwolennik tolerancji wyznaniowej król węgierski, a także polscy protektorzy reformacji i prawosławia. Budny uważał, że działalność świeckich mecenasów jest objawem szczególnej opieki Bożej i tym bardziej należy szanować oraz doceniać ich aktywność na polu szerzenia wiary. Wskazywał na to, że w Sarmacji nadal są mądrzy i zaangażowani panowie, za których trzeba się modlić, przestrzegał zarazem, że nie-

go i greckiego języka na polski wiernie przetłumaczona, Gdańsk: Andrzej Hünefeld 1632, s. 5-7 nlb.

11 Szymon Budny od 1564 roku został przedstawicielem doktryny antytrynitarzy, ale w dedykacji wskazał wielu zasłużonych patronów Kościoła ewangelicko-reformowanego.

12 Jan II Zygmunt Zapolya - król Węgier i książę Siedmiogrodu, w 1568 roku ogłosił wolność wyznania.

13 Mikołaj Radziwiłł Czarny - założyciel linii na Ołyce i Nieświeżu, protektor wyznań reformowanych.

14 Szymon Olelkowicz Słucki (zm. 1592) był protektorem prawosławia.

15 Działaczami reformacyjnymi byli Stanisław, podkomorzy łęczycki, oraz Krzysztof, kasztelan sochaczewski.

16 Mikołaj Oleśnicki (zm. ok. 1566), protektor reformacji w Małopolsce.

17 Hieronim Filipowski (zm. 1574), działacz reformacyjny.

18 S. Budny, Wielmożnemu Panu Jego Miłości Janowi Kiszce, w: Nowy Testament znowu przełożony [...] przez Simona Budnego, Łosk: [Daniel z Łęczycy], nakładem Jana Kiszki, 1574, k. $\mathrm{A}_{4} \mathrm{v}$. 
wdzięczność współwyznawców może spowodować utratę możnych „piastunów”.

Narzekania na brak patronów pojawiły się w obszernym traktacie Pobożnego ewangelika do braciej tegoż wyznania narodu polskiego i litewskiego przestroga i napomnienie, ręka p [ana] Kochlewskiego pisana, w którym - wśród wielu przyczyn zahamowania ruchu reformacyjnego na przełomie XVI i XVII stulecia - wymieniono zmniejszanie się liczby „żywicieli”: „Ubyło patronów, a znacznych patronów, którzy byli nutritor[a]mi Kościoła Bożego"19. Jan Zygrowiusz w kazaniu poświęconym zmarłemu Krzysztofowi Dorohostajskiemu rozwinął myśl o wielkim znaczeniu mecenatu wyznaniowego:

Daleko abowiem większa część ludzi nie poznawa, jaki i jak wielki dar P. Chrystusów jest dobry, sprawiedliwy i miłosierny pan patron gorliwy i pobożny [...]. Chce jeszcze tego P. Chrystus dla postrachu drugim możnym i wielkim stanom, a zwłaszcza oziębłym i niezbożnym panom i patronom. Bierze tedy pobożne i potrzebne patrony i pany, a pod czas i srogą śmiercią, aby onym była ich śmierć pobudką głośną do dobrego ${ }^{20}$.

Pozytywne opinie o zaangażowaniu w problemy współwyznawców pojawiały się jeszcze za życia marszałka litewskiego. Krzysztof Kraiński²1, przypisując Dorohostajskiemu drugą część swojej Postylli²2, podkreślał, że wyróżnia się on

19 Pobożnego ewangelika do braciej tegoż wyznania narodu polskiego i litewskiego przestroga i napomnienie, ręka p[ana] Kochlewskiego pisana, w: U. Augustyniak, Państwo świeckie czy księże?..., s. 179.

20 J. Zygrowiusz, Kazanie na pogrzeb Jaśnie Wielmożnego Pana, Pana Krzysztofa Monwida na Dorostajach, W[ielkiego] Ks[ięstwa] L[itewskiego] najwyższego marszałka odprawowany w Ośmianie Murowanej, Lubcz: Piotr Blastus Kmita, 1616, k. $\mathrm{A}_{4} \mathrm{v}-\mathrm{B}_{1} \mathrm{r}$.

${ }_{21}$ Zob. J. Tazbir, Kraiński Krzysztof h. Jelita, w: Polski słownik biograficzny, t. 15, Wrocław 1970, s. 92-93.

22 W elementach ramowych swoich dzieł kaznodzieja prowadził przede wszystkim żywą polemikę z poglądami katolików i arian, przeciwstawiając im stanowisko ewangelików reformowanych. Zob. J.T. Maciuszko, Ewangelicka postyllografia pol- 
statecznością $\mathrm{w}$ nabożeństwie prawdziwym, także pomnażaniem chwały swej świętej na gruncie W[aszej] M[iłości] i uprzejmą chęcią a miłością przeciwko sługom swoim, o co by wszyscy patronowie Kościoła prawdziwego mieli prosić Pana Boga, aby ich tymże obdarzy ${ }^{23}$.

Kraiński składał adresatowi dedykacji życzenia pomyślności w imieniu swoim i innych ministrów, podkreślając takie cechy Moniwida jak: „chęć, miłość, życzliwość, szczodrobliwość i posłuszeństwo przeciwko sługom Bożym”24. Autor odwoływał się do dobrego wychowania marszałka, wskazywał na rolę jego ojca, który ugruntował w nim wiarę, co zaowocowało tym, że Krzysztof miał być przykładem dla innych w zakresie pogłębiania wiedzy teologicznej:

Przyjmiż tedy W[asza] M[iłość], mój Miłościwy Panie ode mnie, proszę uniżenie, tę pracę moję wdzięcznie, którą pod imieniem W[aszej] M[iłości] przynoszę do progu Kościoła Bożego podług wystarczenia mojego, a inszym bądź W[asza] M[iłość] powodem do czytania jej mając czas. Co, iż W[asza] M[iłość] uczynisz, nie wątpię ${ }^{25}$.

Dorohostajski, sam postrzegany jako „piastun” ewangelików, uznawał wyższość patronatu Krzysztofa Radziwiłła Pioruna ${ }^{26}$. Wielokrotnie pisał na ten temat w listach skierowanych do wojewody wileńskiego; w jednym z nich stwierdzał:

ska XVI-XVIII wieku. Charakterystyka - analiza porównawcza - recepcja, Warszawa 1987, s. 167-168.

${ }^{23}$ K. Kraiński, Postylla Kościoła powszechnego apostolskiego, cz. 2, [Łaszczów 1611], k. $\mathrm{D}_{1} \mathrm{v}$.

${ }^{24}$ Ibidem, k. $\mathrm{D}_{2} \mathrm{r}$.

25 Ibidem.

26 Urszula Augustyniak w artykule poświęconym specyfice patronatu magnackiego w Wielkim Księstwie Litewskim zwróciła uwagę na związki ekonomiczne decydujące o kształtowaniu się fakcji magnackich, ale dodała do tego jeszcze jeden ważny czynnik: „[...] co najmniej równorzędne znaczenie miały związki wyznaniowe, a o trwałości i jakości powiązań wewnątrz układu klientalnego decydował osobisty autorytet patrona". U. Augustyniak, Specyfika patronatu magnackiego w Wielkim Księstwie Litewskim w XVII wieku. Problemy badawcze, „Kwartalnik Historyczny" 109 (2002), nr 1, s. 104. 
To bych też rad widział, quod desidero, że W[aszą] M[iłość] Pan Bóg między wszemi w państwie tem zacnością i godnością, i mądrością tak wyniósł i obdarzył, aby też W[asza] M[iłość] i świętej chwały jego takim prawdziwym chwalcą był, żebyśmy się najniższy słudzy W[aszej] M[iłości] i z tego tak cieszyli jako przystoi, widząc W[aszą] M[iłość] maecenata swego ni divinis et humanis rebus verum cultorem, a Pana Boga im dalej tem więcej za długie i szczęśliwe zdrowie W[aszej] M[iłości] prosili, a W[aszej] M[iłości] $\mathrm{m}$ [emu] M[iłościwemu] P[anu] wiernie służyli ${ }^{27}$.

Po śmierci Pioruna Moniwid nadal związany był z Radziwiłłami birżańskimi i podejmował wspólnie z nimi wiele działań na rzecz ewangelików. Okazją były protesty przeciw tumultom wyznaniowym, między innymi w Wilnie w 1611 roku. Dorohostajski zachęcał wtedy Krzysztofa Radziwiłła do wspólnego sprzeciwu oraz przedstawiał stanowisko króla wobec zamieszek:

Więc i nieszczęsnej tej sprawy zborowej, według błahego przemożenia mego, rad bych dalej dźwigał, nieźle zacząwszy, za nawróceniem jakimkolwiek od P[ana] Boga serca K[róla] J[ego] M[iłości], który i sam żąda takiemu nierządowi słuszny hamulec naleźć, a takowy uraz pro tempore poleczyć [...]. Zaczym i w tem laborare powinność krześcijańska przymusza, ile sił i rozumu stanie. Bez ratunku jednak dźwigania W[aszej] M[iłości] potężniejszych i mędrszych, a bez spólnego porozumienia $\mathrm{z}$ trudna $\mathrm{w}$ to pogodzić, $\mathrm{P}[\mathrm{an}]$ Bóg sam niech utrapionych dźwiga ${ }^{28}$.

Zatargi między katolikami a ewangelikami niezbyt często kończyły się porozumieniem obu stron, więc marszałek, trzeźwo oceniając sytuację w Wilnie, doradzał Radziwiłłowi ostrożność i dyplomację w dochodzeniu krzywd współwyznawców, podkreślał zarazem, jak duże znaczenie ma autorytet księcia oraz wspólne działanie:

Prawdać to, że w tych sprawach zboru Bożego pilno było trzeba porozumienia i namowy gruntownej z Waszmościami [...]. Obejrzawszy się na czasy przeszłe i jako padały podobne sprawy, trzeba by wielkiego w postępku

27 Archiwum Główne Akt Dawnych w Warszawie, Archiwum Radziwiłłów [dalej AGAD, AR], dz. V, 3213, list z 22 IV 1577.

28 Ibidem, list z 12 VIII 1611. 
uważenia, by się przynajmniej, jeśli nie wszystkiego, tedy wżdam tego dopiąć mogło, żeby kwitnieniu dalszym chwały Bożej cokolwiek się uratowało etc. A zatym najdzieli się sposób i po sejmikach może się za konsensem braci naszej przystąpić do jakich śrzodków, które P[an] Bóg raczy sam sprawić i nam podać, a po sejmiku, będzieli wola W[aszej] Ks[iążęcej] M[iłości] tu przybyć do Wilna, jakoś się przyobiecać raczył. Siła by W[aszej] M[iłości] samego authoritas $\mathrm{w}$ pokazaniu w zawziętej chęci Panu pogłaskać mogła i spraw bratnich, i zborowych ${ }^{29}$.

Sprawa tumultu była też dyskutowana w czasie obrad sejmu w 1611 roku i pomimo wielkiego zaangażowania ewangelików w dochodzeniu swoich roszczeń „innowiercy ostatecznie zgodzili się zrezygnować ze swoich żądań, odkładając ich załatwienie do następnego sejmu" ${ }^{30}$. Dorohostajski tak skomentował przebieg obrad w liście do Krzysztofa Radziwiłła:

Sejm ten, jako się zawarł, od inszych W[asza] M[iłość] już dotąd wiedzieć raczysz, a zborowe też sprawy nasze, że ladajako padły, sprawiła to wielka niepotęga nasza, gdyż w senacie jam się jeden znajdował, a między posłami, zwłaszcza naszemi, żaden się nie znalazł, który by albo życzliwie, albo śmiele rzeczy poprzeć chciał. Owa to na $\mathrm{P}$ [ana] Boga włożyć, a na potem się poprawić3 ${ }^{31}$.

W obronę praw dysydentów zaangażowany był także Jan Szwykowski - senior świecki zboru wileńskiego ${ }^{32}$. Józef Łukaszewicz, odwołując się do świadectwa Andrzeja Węgierskiego, przypomniał mowę Szwykowskiego do króla, w której wskazywał na swój status seniora, a upomniany przez księdza Eustachego Wołłowicza miał mu odpowiedzieć: „Nie wstydzi mię ten urząd kościelny, nie cenię

29 Ibidem, list z 13 VIII 1611.

30 T. Kempa, Konflikty wyznaniowe $w$ Wilnie od początku reformacji do końca XVII wieku, Toruń 2016, s. 322.

31 AGAD, AR, dz. V, 3213, list z 13 XI 1611.

32 Zob. T. Kempa, Konflikty wyznaniowe w Wilnie..., s. 315. 
też tak dalece honorów tego świata, abym sprawę Boga mego miał dla nich porzucić”33.

W 1611 roku jako głównych patronów ewangelickich Kraiński przedstawił Jerzego Radziwiłła i Gorajskich. W przypisaniach do kolejnych części swego obszernego dzieła autor wyrażał nadzieję, że spowinowaceni ze sobą magnaci wspólnie będą wspomagali współwyznawców. W pierwszej części Postylli Kraiński, zwracając się z prośbą do Jerzego Radziwiłła: „Bądźże jej W[asza] Ks[iążęca] $\mathrm{M}$ [iłość], uniżenie proszę, patronem i obrońcą od wszystkich nieprzyjaciół, aby się tak pod zasłoną imienia W[aszej] Ks[iążęcej] M[iłości] wiara chrześcijańska rozmnażała i krzewiła” ${ }^{34}$, dodawał, że jego praca ukazała się dzięki wsparciu Piotra Gorajskiego, „męża zaprawdę Kościołowi Bożemu i Rzeczypospolitej wielce potrzebnego, a patrona i dobrodzieja mego wielkiego" ${ }^{35}$. Rodzina Gorajskich została szerzej przedstawiona w przypisaniu do trzeciej części dzieła, skierowanym do Jana z Goraja Lipskiego. Kraiński, nazywając podkomorzego bełskiego „dobrodziejem Kościoła Bożego”, zachęcał go do dalszego dawania przykładu nie tylko potomstwu, ale też współwyznawcom $^{36}$.

Adresatem dedykacji do czwartej części Postylli datowanej na rok 1617 był Rafał Leszczyński, kasztelan wiślicki. Kraiński docenił nie tylko jego zaangażowanie w obronę ewangelików, ale wspominał zasługi ojca wojewody - Andrzeja, „za którego usilnym staraniem złożony był i zebrany synod generalny w Toruniu 1595 dnia 21 sierpnia”, a także Andrzeja Firleja, swego mecenasa i „wielkiego

33 J. Łukaszewicz, Dzieje kościołów wyznania helweckiego w Litwie, t. 1, Poznań 1842 , s. 149.

${ }^{34}$ K. Kraiński, Postylla Kościoła powszechnego apostolskiego, cz. 1 [Łaszczów 1611], k. D $\mathrm{v}$.

35 Ibidem.

36 Idem, Postylla Kościoła powszechnego apostolskiego, cz. 3 [Raków: Sebastian Sternacki 1617], k. [C 2 r].

37 Idem, Postylla Kościoła powszechnego apostolskiego, cz. 4 [Raków: Sebastian Sternacki 1617], k. [D 2 r]. 
dobrodzieja”. Temu ostatniemu Kraiński zadedykował w 1609 roku Kancjonał, podkreślając w przypisaniu wielką wagę śpiewu kościelnego i dowodząc, jak ważną rolę odgrywają świeccy protektorzy $\mathrm{w}$ propagowaniu tej praktyki religijnej:

Mają naukę patronowie w Dawidzie, aby śpiewaniem Pana Boga chwalili, aby przy zborzech szkoły mieli dla chwały Bożej, dla ozdoby kościelnej, żeby minister nie sam śpiewał. Gniewają się dzisia niektórzy, iż w kościelech nie masz porządku w śpiewaniu, a tego nie widzą, iż porządek z strony śpiewania nie może być, jeśli szkoły młodzieńców nie będzie. Nie żałują panowie na śpiewaki domowe, którzy im, by morskie syreny, uszy głaszczą, czasem i wszeteczne pieśni śpiewając, a na śpiewaki kościelne czemu mają żałować kosztu? ${ }^{38}$

Jako przykład dobrego patrona został wskazany adresat dedykacji - Andrzej Firlej, na którym mieli się wzorować inni mecenasi, Kraiński dowodził bowiem, że przypisywanie dzieł służy

więtszemu zaleceniu onych ksiąg, ku pobudce gorętszej, ku pomnożeniu chwały Bożej i dla obrony. Tożem i ja uczynił, pracą swoję W[aszej] M[iłości] przypisałem, wiedząc o pobożności i miłości ku Bogu i Kościołowi Jego świętemu W[aszej] M[iłości], iż W[aszą] M[iłość] Pan Bóg dał niepoślednim patronem Kościołowi swojemu, który nie żałujesz pracej i nakładów dla pomnożenia chwały Bożej, który się zastawiasz, gdzie tego jest potrzeba, o chwałę Bożą, nie dogadzając nikomu, tylko Bogu a sumnieniu swemu $^{39}$.

Rafał Leszczyński był spokrewniony z Firlejami przez matkę, co Kraiński podkreślał w dedykacji do czwartej części Postylli, uznając kasztelana wiślickiego za spadkobiercę i kontynuatora dzieł zmarłego w 1609 roku Andrzeja Firleja.

38 Idem, Jaśnie Wielmożnemu Jego M[iłości] Panu Panu Andrzejowi Firlejowi [...], w: Kancjonał abo pieśni duchowne $z$ naukami i $z$ modlitwami [...], [Raków: Sebastian Sternacki], 1609, k. 24r-24v.

39 Ibidem, k. 38v-39r. 
Patronat Rafała Leszczyńskiego, nazywanego „papieżem kalwinów w Polsce”, miał szeroki zakres. Wojewoda bełski fundował bowiem szkoły i drukarnie, aktywnie wspomagał zbory, między innymi zbór w Lublinie - stał się jego głównym opiekunem i uczestniczył w synodach tamtejszego dystryktu ${ }^{40}$. Ze względu na ekscesy uczniów lubelskich szkół jezuickich występował w obronie współwyznawców, a po zburzeniu zboru ostro przeciwstawił się wyrokowi Trybunału Lubelskiego zakazującemu między innymi jego odbudowy. Rafał Leszczyński był bardzo zaangażowanym mecenasem nie tylko dla kalwinistów, którym udzielał swojego dworu dla odprawiania nabożeństw, ale także dla braci czeskich, którzy w jego dobrach znaleźli schronienie. Jednym z nich był Jan Amos Komeński, pracujący w gimnazjum w Lesznie. Wspieranie szkolnictwa było charakterystycznym rysem działalności patronów ewangelickich, którzy „znaczną część swych dochodów przeznaczali na cele edukacyjne i wydawanie książek, tą drogą upowszechniając wyznania, które reprezentowali" 41 .

Dokonania wojewody bełskiego były dostrzegane także w kręgach katolickich, chociaż interpretowano je jako działania „heretyckie”, na przykład Albrycht Stanisław Radziwiłł na wieść o śmierci Leszczyńskiego odnotował w diariuszu:

Splamił się herezją i uważał się za głowę wszystkich heretyków w Polsce. Odstępstwem od prawdziwej wiary zhańbił swą wiedzę, uczciwość i największe doświadczenie i zamknął sobie dostęp do najwyższych urzędów w Rzeczypospolitej oraz drogę do nieba. [...] Poruszył mnie widok śmierci takiego męża, którego ceniłem jako pożytecznego dla Rzeczypospolitej i dla mnie bardzo miłego. [...] Chory wojewoda wileński wczoraj na wiadomość

40 Por. M. Sipayłło, Leszczyński Rafał h. Wieniawa (1579-1636), w: Polski stownik biograficzny, t. 17, Wrocław 1972, s. 135-139.

${ }_{41}$ I. Lukšaite, Reformacja a przemiany kulturowe w Wielkim Księstwie Litewskim, Poznań 2003, s. 26. 
o śmierci współwyznawcy, wojewody bełskiego, jeszcze bardziej się rozchorowal ${ }^{42}$.

Kanclerz mimowolnie poświadczył nie tylko wielkie zalety Leszczyńskiego, ale wskazał na silne powiązania między nim a swoim krewnym - Krzysztofem Radziwiłłem. Po śmierci księcia birżańskiego wystawił mu zresztą pochlebną opinię:

Wojewoda wileński, mój stryjeczny, niekatolik, w nocy w obecności niewielu osób wyzionął ducha $\mathrm{z}$ najwyższym żalem Rzeczypospolitej, która opłakiwała stratę tak wielkiego senatora. Śmierć ta mocno ugodziła przywiązanego doń króla, ale najbardziej dotknęła dysydentów. Ci opłakiwali przywódcę swej sekty i trwożyli się w duchu, że padła podpora ich spraw. Żałować tylko należy, że w tak mądrym mężu brakowało prawdziwego światła wiary; gdyby nie to, każdy przyznałby, że był obdarzony wszystkimi cnotami i mądrością ${ }^{43}$.

Pełne sprzeczności charakterystyki ewangelickich patronów były jednak odosobnione, zwłaszcza w drukowanych panegirykach współwyznawców. Maciej Głoskowski tak opisywał zmarłego wojewodę bełskiego w dziele Sława potomna:

Tyżeś to, o przezacny Leszczyński Rafale,

Takim razem miał polec, któryś w Bożej chwale

Przodku nie dał nikomu, ani w pobożności [...].

Poległeś życzliwego poddaństwa patronie,

Których serca przenika na obiedwie stronie

Ból niezwykły, poległeś ludzi utrapionych

Opiekunie i nędzą ostatnią ściśnionych.

Ręka twa potrzebnemu nie była skurczona

Ani twarz od ubogich skwirku odwrócona ${ }^{44}$.

42 A.S. Radziwiłł, Pamiętnik o dziejach w Polsce, przeł. i oprac. A. Przyboś, R. Żelewski, Warszawa 1980, t. 1, s. 529.

${ }^{43}$ Ibidem, t. 2, s. 222-223.

44 M. Głoskowski, Sława potomna Jaśnie Wielmożnego Pana jego M[iłości] Pana Rafata hrabie z Leszna wojewody betskiego, [b.m. 1636], k. $\mathrm{B}_{3} \mathrm{r}-\mathrm{B}_{4} \mathrm{r}$. 
Głoskowski podkreślał przede wszystkim wrażliwość wojewody na biedę oraz hojne wspieranie ubogich, nie poświęcił natomiast większej uwagi jego konkretnym działaniom fundatorskim. Podobnie przedstawił $\mathrm{w}$ druku pogrzebowym syna - imiennika Rafała Leszczyńskiego - Andrzej Węgierski, który przekonywał, „że ten zacny pan na tym żałosnym żałobnym przed oczy nasze wystawiony katafalku był statecznym imienia Pańskiego i jego ś[więtej] Ewangeliej wyznawcą [...]. Dobroczynności jego doznawali słudzy Boży $\mathrm{i}$ inszy ludzie" ${ }^{\prime 4}$.

Zwracanie uwagi na miłosierny stosunek patronów do poddanych i podkreślanie, że jest to o wiele ważniejsze niż wznoszenie nowych świątyń, tak ujmował Krzysztof Kraiński:

A wszakoż budując kościoły ubogich nie zapominajmy, bo chociabyśmy sto kościołów zbudowali, a nad jednym się ubogim nie zmiłujemy, nic nam to nie pomoże, gdyż na sądzie nie będą przypominać budowania kościołów, ale uczynność przeciw ludziom ubogim ${ }^{46}$.

Nieco dalej autor Postylli wyjaśniał też zasady harmonijnego współżycia przełożonych i poddanych, dowodząc, że panowie powinni starać się o powierzonych sobie ludzi, a oni z kolei mają szanować i respektować wolę patronów:

Poddanym też jest tu nauka, aby zwierzchności najwyższej ziemskiej, której dobrodziejstwa zażywają, poddanemi i posłusznemi byli. Tak bowiem uczy Paweł święty: Każdy człowiek niechaj będzie poddany zwierzchnym przełożeństwom. Abowiem nie jest przełożeństwo jedno od Boga, a przełożeństwa, które bywają od Boga, są porządnie postanowione. Przeto, który się zastawuje przełożeństwu, sprzeciwia się postanowieniu Bożemu, a którzy się sprzeciwiają, oni na się karanie wnoszą̨

45 A. Węgierski, Kazanie o stateczności w wierze [...] na pogrzebie [...] Rafała Leszczyńskiego, wojewodzica bełskiego, Baranów: Jerzy Twardomęski, 1644, k. B $\mathrm{B}_{3}$.

${ }^{46}$ K. Kraiński, Postylla Kościoła powszechnego apostolskiego, cz. 1, k. 84r.

47 Ibidem, k. 85r. 
Podobne poglądy na temat wielkiego znaczenia zwierzchności świeckiej sformułował Jan Kalwin, który głosił, że „urząd pozwierzchni, który świeckim zowiemy, nie tylko Bóg znacznie pochwala, ale go też wielkimi nazwiskami tytułuje; za czym wielce go nam zaleca"48. Kraiński dawał panom konkretne wskazówki, jak się mają obchodzić z poddanymi i sługami:

Aby się starali o zbawienie sług swoich. A jakoż? Niech ich z sobą wodzą na słuchanie słowa Bożego, niech się za nie Panu Bogu modlą, onych niech napominają słowy pięknemi, rozwodząc im wolą Bożą i onym niech będą dobrym przykładem ${ }^{49}$.

Oprócz zawartych w przypisaniach i panegirykach uwag o zasługach i obowiązkach mecenasów konkretne zalecenia dotyczące działalności świeckich patronów i seniorów znalazły się w dokumetacji synodalnej, w której wielokrotnie podkreślano konieczność sprawowania opieki przez możnych współwyznawców. Relacje między panami a podwładnymi porównywano nawet do stosunków rodzinnych i ostrzegano, że za niewłaściwe traktowanie dzieci i poddanych Bóg będzie rozliczał na sądzie ostatecznym:

Vienetos sinoduose tai buvo nusakomakaip priedermè: „Visu dievoty patronu pareiga yra vesti savo pavaldinius prie Dievo žodžio. [...] Be to, sinodas visų Ponų, kurie savo valdose yra įsteigę bažnyčias, ypač prašo ir primena, kad patys kartu su savo vietininkais pavaldiniams bütu dievotumo pavyzdžiu, nes kaip tèvai už vaikus, taip žemvaldžiai už pavaldinius atsiskaitys Dievui Paskutiniame teisme." Radvilos, siekdami, kad pavaldiniai nuolatdalyvautu

48 J. Kalwin, O zwierzchności świeckiej, porządne, według sznuru Pisma świętego opisanie. Zaraz o pożytkach i powinnościach urzędu jej. Z łacińskiego na polskie wiernie przettumaczone. Anonimowy przekład polski dwudziestego rozdziału ksiegi „Institutio religionis nunc uere demum suo titulo respondens" Jana Kalwina wydany w 1599 r., oprac. W. Kriegseisen, Warszawa 2009, s. 61.

49 K. Kraiński, Postylla Kościoła powszechnego apostolskiego, cz. 1, k. 85r. 
bažnytinèse pamaldose, ragino kunigus „nepalikti gero ir švento papročio [...] lankyti klausytojus miesteliuose ir kaimuose ${ }^{\text {"so }}$.

W Kościele ewangelicko-reformowanym wielką wagę przywiązywano również do roli świeckich seniorów; patroni wielokrotnie pełnili te funkcje, na przykład Zbigniew Gorajski, który przewodził kalwinistom lubelskim i małopolskim. W 1628 roku lubelski synod dystryktowy „zwrócił się z prośbą do patronów, aby wyznaczyli spośród siebie seniorów «a osobliwie jmp. Zbigniewa Gorajskiego, aby to munus senioratus przyjąć na siebie raczył»" ${ }^{51}$. Zięć Rafała Leszczyńskiego mocno zaangażował się w życie Jednoty: opiekował się ministrami i alumnami, nadzorował finanse Kościoła oraz działalność szkoły prowincjonalnej w Bełżycach, wspomagał drukarnię w Baranowie, interesował się planowanymi tam do wydania pracami, opiniując je i współpracując $z$ autorami, między innymi Janem Amosem Komeńskim $^{52}$. W czasie przygotowań do Colloquium Charitativum odegrał też znaczącą rolę w obozie ewangelików reformowanych. Mimo że później Gorajski zrezygnował z części obowiązków seniora świeckiego, gdyż pochłaniały go inne prace, między innymi działalność w senacie ${ }^{53}$, nadal bronił praw swoich współwyznawców na sejmach, fundował nowe zbory.

Zakres powinności patronów i seniorów świeckich był nieco inny, obowiązki i zasady wyboru tych ostatnich formułowano w czasie sesji zborowych, na przykład w Kiejdanach, gdzie postulowano, aby „[...] obierani byli ludzie poćciwi, Pana Boga się bojący, nullius criminis suspecti, trzeźwi, którzy by [...] wespół z pasterzami o dobrym

50 D. Karvelis, Iš Radvilų giminès istorijos. Biržų kunigaikštystè ir jos visuomenè 1547-1655 metais, Vilnius 2015, s. 443.

51 D. Kupisz, Zbigniew Gorajski (1596-1655). Studium z dziejów szlachty protestanckiej w Małopolsce w pierwszej połowie XVII wieku, Warszawa 2000, s. 76.

52 Por. ibidem, s. 79-81, 151-152.

53 Por. ibidem, s. 145. 
porządku Kościoła Bożego obmyślać mogli” ${ }^{54}$. Tak wybrani seniorzy mieli wypełniać zadania dotyczące między innymi kontroli godnego zachowania współwyznawców i ministrów:

Aby pospołu z pasterzami czuli nad trzodą Bożą i żeby się zgorszenia jako pijaństwa, wszeteczeństwa, cudzołóstwa i inne tym podobne nie działy postrzegali, a gdzie by takowego co było, tedy takowych występnych $\mathrm{z}$ urzędu swego napomnieć i z słowa Bożego karać, pasterze o tym ostrzygać powinni, nie mając względu na osoby, dary, klientelę, ale spólnie od zgorszenia Dom Pański oczyścili, a chwałę Bożą rozmnażali.

Więc i na same pasterze pilne mieć mają oko, aby prawdziwą chrześcijańską naukę szczyrze, wiernie i pilnie przekładali i żywot pobożny sami i ich spółpracownicy wiedli. A jeśliby którego zgorszenie czyniącego obaczyli, onego pod sumieniem upomnieć, a gdyby był nieposłuszny starszym i synodowi lub personaliter lub przez list odnieść mają ${ }^{55}$.

Członkowie kolegialnych władz zborów mieli nie tylko kontrolować „pasterzy”, ale z racji sprawowanej funkcji przypominać patronom o potrzebie ich obrony i wspomagania finansowego: „Z władzy urzędu swego mają moc upomnieć panów i zwierzchność, i namiestniki ich, aby słudzy Boży opatrzenie i pomieszkanie przystojne mieli i krzywd, i ucisków żadnych nie cierpieli” ${ }^{56}$. Na seniorach spoczywał z kolei obowiązek regularnego uczestniczenia w sesjach oraz doglądania „[... aby wszystko porządnie i przystojnie w Kościele Bożym odprawowało się" ${ }^{57}$. Ponadto powinni oni pilnować realizacji postanowień podjętych na sesjach zborowych ${ }^{58}$. Wyliczone zadania skupiały się przede wszystkim na wzajemnym kontrolowaniu się współwyznawców i pobudzaniu do większej gorliwości religijnej.

54 Anno MDCXXX dnia 3 maja sesja zborowa na wizytacyjej przed synodem wileń[skim] będąca, w: Collecta zboru kiejdańskiego 1628-1663, Biblioteka Narodowa Litwy im. Martynasa Mažvydasa, rkps F 93-540, s. 60.

55 Ibidem.

56 Ibidem.

57 Ibidem.

58 Ibidem. 
Jednym z seniorów świeckich w Kiejdanach był Piotr Kochlewski, który z zaangażowaniem starał się wypełniać te obowiązki. W 1631 roku zapisał własną ręką postulaty wynikające $\mathrm{z}$ wizytacji tamtejszego zboru, między innymi dopominał się o wspieranie miejscowego szkolnictwa: „Panów mieszczan admoneri, aby nie byli ciężcy i drodzy w przyjmowaniu dziatek szlacheckich do stołów swych za słusznym najmem dla rozmnożenia szkoły" ${ }^{59}$. Chcąc dać przykład innym, namiestnik kiejdański wraz z tamtejszymi burmistrzami zdeklarował pomoc „młodzieńcom, którzy by skądinąd tu do szkoły przyszli. Ea conditione żeby tym, co Bóg da, nie brakowali, żeby dziatki ich do szkoły wodzili, żeby ich privatim doglądali” ${ }^{60}$. Kochlewski wielokrotnie był też wskazywany w litewskich aktach synodów prowincjonalnych, podobnie jak inny senior związany z birżańskim dworem Radziwiłłów - Daniel Naborowski ${ }^{61}$. W tym źródle znalazły się także zalecenia dotyczące obowiązków patronów, werbalizujące oczekiwania na przykład odnośnie do wizytacji:

Patron każdy, albo starosta na jego miejscu będący, ma doglądać krzywdy poddanych plebańskich, a jeśli jaka skarga będzie na ministra, tedy pan patron ma napomnieć ministra, a jeśliby słuchać nie chciał, ma do superintendenta pisać, aby zjachał i skargi pomiarkował, a jeśliby minister słuchać nie chciał, tedy do synodu odnieść. A jeśliby też patron skargi od ministra słuchać nie chciał, tedy ma do superintendenta pisać, aby patrona napomniał ${ }^{62}$.

Podawano także konkretne sposoby finansowego wspierania poszczególnych zborów i szkół: „Postanowiono, aby panowie patronowie i słuchacze u każdego zboru co rok do skrzynki zborowej, jako im Bóg poda, dla poratowania zboru Bożego i szkół chrześcijańskich

59 Conclusie przy wizytacyjej w Kiejdanach 1631 [die] 16 Iunii odprawowanej, w: Collecta zboru kiejdańskiego 1628-1663..., s. 15.

60 Collecta zboru kiejdańskiego 1628-1663..., s. 8.

${ }^{61}$ Akta synodów prowincjalnych Jednoty Litewskiej 1626-1637, oprac. M. Liedke, P. Guzowski, Warszawa 2011, s. 63.

${ }^{62}$ Akta synodów prowincjalnych Jednoty Litewskiej 1611-1625, Wilno 1915, s. $35-36$. 
z czasem przypadających, składali"63. Patroni powinni dbać o plebanie, do czego zobowiązywało ich następujące postanowienie synodalne: „Jeśli znowa plebanią budować, albo po pogorzeniu nową wystawiać przyjdzie, rozumieją bracia, że to ma czynić patron swymi chłopkami i swym sumptem, a nie minister"64. Nieraz te oczekiwania nie były spełniane, więc wprost formułowano zarzuty dotyczące między innymi opustoszałych świątyń:

Iż na mnogich miejscach zbory Boże bez ministrów wakują, drugie są w swych kondycjach okąszone, insze ledwo nie funditus wywrócone są, a to się wszytko po wielkiej części dzieje (żal się Boże) niedbałością panów patronów tamtych miejsc lub też przyczyną inszych person rozmnożeniu chwały Bożej nieżyczliwych ${ }^{65}$.

Na tym samym generalnym synodzie wileńskim w 1622 roku odnotowano niedbałość „oziębłych patronów”, którzy nie angażują się w życie Jednoty: „Aby ruinie zborów jako napilniej zabiegano. A to względem oziębłych patronów, co mogąc ministry chować i zbory zakładać, nie czynią nic, u drugich wszędzie pustki, trzeci futuris rebus non prospiciunt, skąd pewny upadek"66.

W zapiskach tych nie odnotowano nazwisk związanych z konkretnymi negatywnymi przykładami, odwrotnie niż przy wyliczaniu zasług: fundatorów drukarni (Pakosz) ${ }^{67}$ czy sponsorów wydania publikacji religijnych (Jarosz Jewłaszewski - Apologia Krowickiego ${ }^{68}$, Adam Talwosz kasztelan żmudzki i Jan Szwykowski - Katolik reformowany Zygrowiusza ${ }^{69}$, Dawid Szwykowski - polemiczna odpowiedź $\operatorname{arianom}^{70}$ ).

\footnotetext{
63 Ibidem, s. 37.

64 Ibidem, s. 41.

65 Ibidem, s. 67.

66 Ibidem, s. 71.

67 Ibidem, s. 32.

68 Ibidem.

69 Ibidem, s. 102-103.

$70 \quad$ Ibidem, s. 36.
} 
W aktach litewskich synodów najwięcej informacji o działaniach patronackich dotyczyło księcia Krzysztofa Radziwiłła ${ }^{71}$, wielokrotnie wymienianego jako fundatora stypendiów studiów zagranicznych dla alumnów, którzy po zdobyciu wykształcenia „posługami swymi zborowi wileńskiemu obowiązani będą"72. Hetman deklarował swoją gotowość materialnej pomocy przy organizowaniu szkół w Słucku i Kiejdanach: obiecał sumpt na preceptorów i zbudowanie im miesz$\mathrm{kania}^{73}$. Akta z 1625 roku wymieniają go również jako nakładcę pośmiertnej edycji prac Baltazara Krośniewicza ${ }^{74}$.

Świecki patron litewskich kalwinistów wspomagał współwyznawców nie tylko pod względem finansowym, proszono go także o radę w sprawach merytorycznych, na przykład przy ocenie ksiąg. W 1620 roku miał wydać ostateczną decyzję w sprawie przyjęcia fragmentu o Wieczerzy Pańskiej w katechizmie Jana Zygrowiusza: „która się z tych obudwu form będzie podobała Książęciu Jego M[iło]ści panu hetmanowi, ta ma być do druku podana"75. Jak stwierdziła Paulina Buchwald-Pelcowa: „W tym więc punkcie protektor został postawiony ponad synodem, on był najwyższą instancją dla cenzury zborowej, przynajmniej w tym przypadku"76. Baltazar Krośniewicz w liście ze Słucka z 9 lipca 1620 roku również podkreślał respektowanie ostatecznej aprobaty hetmana dla niektórych fragmentów katechizmu, gdyż w zależności od tego, którą z zaproponowanych wersji uzna on za „porządniejszą i do wybudzenia skutku w człowieku sposobniej-

71 Po śmierci Krzysztofa Radziwiłła, 17 listopada 1640 roku ukazała się informacja w „Gazette de France”, w której przedstawiono zmarłego księcia jako główną ostoję protestantyzmu w Polsce. Zob. T. Wasilewski, Uwagi wstępne, w: B. Radziwiłł, Autobiografia, wstęp i oprac. T. Wasilewski, Warszawa 1979, s. 25.

72 Akta synodów prowincjalnych Jednoty Litewskiej 1611-1625..., s. 79.

73 Ibidem, s. 96.

74 Ibidem, s. 102.

75 Ibidem, s. 55.

76 P. Buchwald-Pelcowa, Cenzura w dawnej Polsce. Między prasa drukarska a stosem, Warszawa 1997, s. 185. 
szą, ta drukowana będzie"77. Od księcia Krzysztofa zależało także rozpowszechnienie katechizmu, więc Krośniewicz 11 czerwca 1618 roku zwracał się do niego z następującą prośbą: „Nic nie pozostawa jedno, abyś W[asza] Ks[iążęca] M[iłość] jako pa[n] krześcijański, chwałę Bożą miłujący nie przeszkadzał, ale pomagał łaską swą miłościwą, aby mógł być między ludzie posłany"78.

Szczególną wdzięczność okazywali hetmanowi jego duchowni klienci, traktując go - by użyć słów księdza Orlicza - „jako drzewo wspaniałe, ochraniające swymi gałęziami”79. Podobną metaforą posłużył się Marcin Widziewicz w kazaniu pogrzebowym wygłoszonym po śmierci Mikołaja Krzysztofa Radziwiłła Sierotki:

Pan abo Książę jest drzewem onym wielkim i wysokim u Daniela proroka opisanym, którego liście barzo piękne i owoc pełny, pod którym jako źwierzątka niejakie wszystka czeladka domowa i poddani, a na gałązkach jego namilsze dziatki i potomstwo jako ptaszątka powietrzne mieszkają, a z niego pokarmu czeka każde ciało. Jakoż takiego drzewa, tak wielom pożytecznego, gdy ze wszystkim od śmierci nieużytej podcięte upada z serca nie żałować? ${ }^{80}$

Patrona, który niczym drzewo zapewnia ochronę i dostatek poddanym oraz rodzinie, inaczej jednak widzieli katolicy i ewangelicy reformowani. W przypisaniach protestanckich eksponowano takie zasługi mecenasów, jak: wspieranie ministrów i zborów, sponsorowanie placówek oświatowych, studiów młodzieży czy publikacji, a także troska o biednych. Autorzy dedykacji skierowanych do ewangelików podkreślali, że takie działania są ważniejsze niż finansowa-

77 AGAD, AR, dz. V, 7801.

78 Ibidem.

79 Cyt. za: U. Augustyniak, Duchowni klienci Krzysztofa II Radziwiłła. Kondycja $i$ funkcje duchowieństwa ewangelicko-reformowanego $w$ dobrach radziwiłtowskich w pierwszej połowie XVII wieku, w: Radziwiłtowie XVI-XVIII wieku. W kregu polityki i kultury, [kom. red. E. Potkowski et al.], Warszawa 1989 (Miscellanea Historico-Archivistica, t. 3), s. 173.

${ }_{80}$ M. Widziewicz, Kazanie na pogrzebie Jaśnie Oświeconego Pana Jego M[ił] ości Pana Mikołaja Krzysztofa Radziwita [...], Kraków: Franciszek Cezary, 1616, s. 5-6. 
nie budowy okazałych świątyń, co mogło być aluzją do przykładania wielkiej wagi do takiego „materialnego” wymiaru mecenatu patronów wyznania rzymskiego. W przypisaniach pojawiały się także apele do kalwinistów, aby modlili się za swych panów, byli im posłuszni i doceniali ich zaangażowanie, gdyż utrata patrona osłabia wspólnotę wyznaniową. W dokumentacji synodalnej można znaleźć potwierdzenie działań Radziwiłłów, Leszczyńskich, Gorajskich i Firlejów na rzecz ewangelików reformowanych, a także precyzyjne wskazówki dotyczące zakresu kompetencji, uprawnień, ale i wymagań wobec patronów i seniorów świeckich. Krytykowano wszelkie zaniedbania w tym zakresie, nie precyzując jednak, którzy „oziębli” patroni uchylają się od swych obowiązków. Przypisywanie wielkiego znaczenia mecenatowi wyznaniowemu potwierdzają nie tylko akta synodalne, ale także listy i testamenty patronów, będące świadectwem ich wielkiego zaangażowania w rozwój reformacji.

\section{Bibliografia}

\section{Źródła}

Akta synodów prowincjalnych Jednoty Litewskiej 1611-1625, Wilno 1915.

Akta synodów prowincjalnych Jednoty Litewskiej 1626-1637, oprac. M. Liedke, P. Guzowski, Warszawa 2011.

Anno MDCXXX dnia 3 maja sesja zborowa na wizytacyjej przed synodem wileń[skim] będąca, w: Collecta zboru kiejdańskiego 1628-1663, Biblioteka Narodowa Litwy im. Martynasa Mažvydasa, rkps F 93-540.

Archiwum Główne Akt Dawnych w Warszawie, Archiwum Radziwiłłów [AGAD, AR], dz. V, 3213; dz. V, 7801.

Biblia święta, to jest Księgi Starego i Nowego Zakonu, właśnie z żydowskiego, greckiego i łacińskiego, nowo na polski język z pilnością i wiernie wyłożone, Brześć: [Stanisław Murmelius lub Cyprian Bazylik], nakładem Mikołaja Radziwiłła, 1563.

Budny S., Wielmożnemu Panu Jego Miłości Janowi Kiszce, w: Nowy Testament znowu przełożony [...] przez Simona Budnego, Łosk: [Daniel z Łęczycy], nakładem Jana Kiszki, 1574. 
Conclusie przy wizytacyjej w Kiejdanach 1631 [die] 16 Iunii odprawowanej, w: Collecta zboru kiejdańskiego 1628-1663, Biblioteka Narodowa Litwy im. Martynasa Mažvydasa, rkps F 93-540.

Głoskowski M., Sława potomna Jaśnie Wielmożnego Pana jego M[iłości] Pana Rafała hrabie z Leszna wojewody bełskiego, [b.m. 1636].

Kalwin J., O zwierzchności świeckiej, porządne, według sznuru Pisma świętego opisanie. Zaraz o pożytkach i powinnościach urzędu jej. Z łacińskiego na polskie wiernie przetłumaczone. Anonimowy przekład polski dwudziestego rozdziału księgi „Institutio religionis nunc uere demum suo titulo respondens” Jana Kalwina wydany w 1599 r., oprac. W. Kriegseisen, Warszawa 2009.

Kawieczyńscy H.A., Oświeconemu Książęciu i Panu, Panu Mikołajowi Radziwiłłowi [...], w: Biblia, to jest Księgi Starego i Nowego Przymierza znowu z języka ebrajskiego, greckiego i łacińskiego na polski przełożone, [Nieśwież, Zasław lub Uzda]: Daniel z Łęczycy, nakładem Macieja, Hektora i Adama Kawieczyńskich, 1572.

Kraiński K., Jaśnie Wielmożnemu Jego M[iłości] Panu, Panu Andrzejowi Firlejowi [...], w: Kancjonał abo pieśni duchowne z naukami i z modlitwami [...], [Raków: Sebastian Sternacki], 1609.

Kraiński K., Postylla Kościoła powszechnego apostolskiego, cz. 1-2 [Łaszczów 1611], cz. 3-4 [Raków: Sebastian Sternacki, 1617].

Oświeconemu Książęciu a Panu Jego Książęcej Mości Panu Krzysztofowi Radziwitłowi, w: Biblia święta, to jest Księgi Starego i Nowego Przymierza z żydowskiego i greckiego języka na polski wiernie przettumaczona, Gdańsk: Andrzej Hünefeld, 1632.

Pobożnego ewangelika do braciej tegoż wyznania narodu polskiego i litewskiego przestroga i napomnienie, ręka p [ana] Kochlewskiego pisana, w: U. Augustyniak, Państwo świeckie czy księże? Spór o rolę duchowieństwa katolickiego w Rzeczypospolitej w czasach Zygmunta III Wazy. Wybór tekstów, Warszawa 2013.

Radziwiłł A.S., Pamiętnik o dziejach w Polsce, t. 1-3, przeł. i oprac. A. Przyboś, R. Żelewski, Warszawa 1980.

Wawrzyniec z Przasnysza, Nauka o prawdziwej i o fałszywej pokucie [...], Pińczów: Daniel z Łęczycy, 1559.

Węgierski A., Kazanie o stateczności w wierze [...] na pogrzebie [...] Rafała Leszczyńskiego, wojewodzica bełskiego, Baranów: Jerzy Twardomęski, 1644.

Widziewicz M., Kazanie na pogrzebie Jaśnie Oświeconego Pana Jego M[ił]ości Pana Mikołaja Krzysztofa Radziwiła [...], Kraków: Franciszek Cezary, 1616.

Zygrowiusz J., Kazanie na pogrzeb Jaśnie Wielmożnego Pana, Pana Krzysztofa Monwida na Dorostajach, W[ielkiego] Ks[ięstwa] L[itewskiego] najwyższego marszałka odprawowanyw w Ośmianie Murowanej, Lubcz: Piotr Blastus Kmita, 1616. 


\section{Opracowania}

Augustyniak U., Duchowni klienci Krzysztofa II Radziwiłła. Kondycja i funkcje duchowieństwa ewangelicko-reformowanego $w$ dobrach radziwiłłowskich $w$ pierwszej połowie XVII wieku, w: Radziwiłłowie XVI-XVIII wieku. W kregu polityki $i$ kultury, [kom. red. E. Potkowski et al.], Warszawa 1989 (Miscellanea Historico-Archivistica, t. 3).

Augustyniak U., Państwo świeckie czy księże? Spór o rolę duchowieństwa katolickiego w Rzeczypospolitej w czasach Zygmunta III Wazy. Wybór tekstów, Warszawa 2013.

Augustyniak U., Specyfika patronatu magnackiego $w$ Wielkim Księstwie Litewskim w XVII wieku. Problemy badawcze, „Kwartalnik Historyczny” 109 (2002), nr 1.

Bagińska E., Tolerancja czy przymus wyznaniowy? Z dziejów polityki religijnej Radziwiłłów birżańskich, w: Studia nad reformacją, red. E. Bagińska, P. Guzowski, M. Liedke, Białystok 2010.

Buchwald-Pelcowa P., Cenzura $w$ dawnej Polsce. Między prasa drukarską a stosem, Warszawa 1997.

Jarczykowa M., Radziwiłłowie birżańscy jako protektorzy wyznania ewangelicko-reformowanego w pierwszej połowie XVII wieku, w: Dialog z Europa i aksjologia ewangelików reformowanych w świetle literatury i piśmiennictwa XVI-XVII wie$k u$, red. D. Chemperek, Warszawa 2015.

Karvelis D., Iš Radvilu gimines istorijos. Biržu kunigaikštystè ir jos visuomené 15471655 metais, Vilnius 2015.

Kempa T., Konflikty wyznaniowe $w$ Wilnie od początku reformacji do końca XVII wieku, Toruń 2016.

Krasiński W., Walki religijne $w$ Polsce, czyli zarys dziejów powstania i upadku reformacji w Polsce, Toledo 1925.

Kupisz D., Zbigniew Gorajski (1596-1655). Studium z dziejów szlachty protestanckiej w Małopolsce w pierwszej połowie XVII wieku, Warszawa 2000.

Lukšaite I., Reformacja a przemiany kulturowe w Wielkim Księstwie Litewskim, Poznań 2003.

Łukaszewicz J., Dzieje kościołów wyznania helweckiego w Litwie, t. 1, Poznań 1842.

Maciuszko J.T., Ewangelicka postyllografia polska XVI-XVIII wieku. Charakterysty$k a$ - analiza porównawcza - recepcja, Warszawa 1987.

Paknys M., Mecenat, w: Kultura Wielkiego Księstwa Litewskiego. Analizy i obrazy, oprac. V. Ališauskas, L. Jovaiš, M. Paknys, R. Petrauskas, E. Raila, Kraków 2006.

Sipayłło M., Leszczyński Rafał h. Wieniawa (1579-1636), w: Polski słownik biograficzny, t. 17, Wrocław 1972.

Tazbir J., Kraiński Krzysztof h. Jelita, w: Polski słownik biograficzny, t. 15, Wrocław 1970.

Wasilewski T., Uwagi wstępne, w: B. Radziwiłł, Autobiografia, wstęp i oprac. T. Wasilewski, Warszawa 1979. 